\title{
Idiopathic hypoglycaemia in sibs with morphological evidence of nesidioblastosis of the pancreas
}

\author{
D. WOO, J. W. SCOPES, * and J. M. POLAK \\ From the Department of Paediatrics and Neonatal Medicine, and Department of Histochemistry, \\ Hammersmith Hospital, London
}

\begin{abstract}
Woo, D., Scopes, J. W., and Polak, J. M. (1976). Archives of Disease in Childhood, 51, 528. Idiopathic hypoglycaemia in sibs with morphological evidence of nesidioblastosis of the pancreas. Two sibs who sustained severe hypoglycaemia in the neonatal period are reported. In spite of treatment with frequent feeds, intravenous glucose, glucagon, hydrocortisone, and diazoxide, hypoglycaemia persisted, and both infants eventually required subtotal pancreatectomy. Tests for leucine tolerance were normal though the second case showed some protein sensitivity. Histological and immunohistochemical studies indicated nesidioblastosis in both specimens of pancreata. The children are presently performing at mildly retarded levels, and required diazoxide and anticonvulsant medication for some time postoperatively.

Because both sexes are represented, an autosomal recessive inheritance pattern is suggested. The theory of a gut hormone stimulating insulin production is briefly discussed.
\end{abstract}

The term 'nesidioblastosis' has been used (Bloodworth and Elliott, 1963; Yakovac, Baker, and Hummeler, 1971; Grampa et al., 1974; Davidson, Blackwood, and Fox, 1974) to describe the presence of numerous abnormal clusters (nesidio-islet) of $\beta$-cells, thought to be differentiated from pancreatic ductal cells. The clinical and pathological features and associations with other syndromes have been published (Yakovac et al., 1971; Grampa et al., 1974; Davidson et al., 1974; Brown and Still, 1968; Vance et al., 1972; Brown and Madge, 1971; Sovik, Vidnes, and Falkmer, 1975). We now report its occurrence in sibs who presented with neonatal hypoglycaemia in which the diagnosis was confirmed using immunohistochemical techniques as well as methods previously described. A short report on one of them has been published (Stern, 1973).

\section{Case reports}

Parents. The parents are Greek Cypriots with no known family history of consanguinity, diabetes, or unexplained neonatal deaths. Glucose tolerance tests on both parents were normal. There are 3 children.

Received 6 October 1975.

^Present address: Neonatal Research Unit, St. Thomas's Hospital, $\star$ Prese
London.
The middle child is quite normal; the other two are described below.

\section{Case 1.}

Presentation. The first child, a girl, was born at term weighing $2.94 \mathrm{~kg}$. Her mother was then 26 years old and pregnancy and delivery were normal She was well on breast and bottle feeds until the third day when she was lethargic and feeding poorly; blood glucose concentration was $11 \mathrm{mg} / 100 \mathrm{ml}$.

Investigations. An intravenous glucose tolerance test measuring also insulin and lactate showed (1) an inappropriately high fasting insulin level of $23 \mu \mathrm{U} / \mathrm{ml}$ (normal adult levels 3-20 $\mu \mathrm{U} / \mathrm{ml}$ ) when her blood glucose was $9 \mathrm{mg} / 100 \mathrm{ml}$; and (2) a glucose disappearance rate of $2 \cdot 9 \mathrm{mg} / 100 \mathrm{ml}$ permin (normal $1 \cdot 8$ ). Every blood insulin test performed was higher than $20 \mu \mathrm{U} / \mathrm{ml}$. Lactates were normal, as were the following: cultures for infection; urine for reducing substances; serum calcium, magnesium, and phosphate; leucine sensitivity test; and glucagon response test.

Treatment and progress. She was treated at first with glucagon and hydrocortisone with frequent feeds but blood sugars were only moderately maintained. Diazoxide $(13 \mathrm{mg} / \mathrm{kg}$ per day) was substituted with hydrochlorothiazide to minimize sodium retention. By 11 weeks she showed evidence of seizures both clinically and on electroencephalogram, fits occurring even 
when she was normoglycaemic. Phenytoin was added to her treatment. Her head circumference failed to increase adequately, falling from the 50th centile to the 5 th centile, and she had poor auditory, visual, and social responsiveness.

Hypoglycaemia recurred during intercurrent infection and anorexia, so that at 6 months she had a laparotomy. No $\beta$-cell adenoma could be found so subtotal pancreatectomy (and incidental splenectomy) was performed. Postoperatively she had a short period of hyperglycaemia but then reverted to a near-hypoglycaemic state which now, however, was adequately controlled with diazoxide. This was discontinued at $4 \frac{1}{2}$ years of age after which it was found that an overnight fast no longer caused hypoglycaemia. Phenytoin was stopped at 6 years; she has had no fits since the age of 5 years. She is now mildly retarded but is a cheerful, pleasant, and much loved child, and attends a special school.

Histology of pancreas. At the time of operation (1967) we were unaware of the condition. The histology was merely thought to show pleomorphism of the $\beta$-cell nuclei and poor granulation suggesting $\beta$-cell stimulation by an unknown agent. We hypothesized an insulinreleasing hormone produced from the gut such as has been described in rats (Turner and Marks, 1972). Recent re-examination of the histology from this case shows diffuse hyperplasia of $B$ (insulin-) and $A$ (glucagon-producing) cells of the pancreas.

\section{Case 2.}

Presentation. The third child, a boy, was born near term when his mother was 32 years old. Pregnancy and delivery were normal, birthweight $3.58 \mathrm{~kg}$. He was breast-fed and appeared to do well; in view of the history of his sister, blood glucose levels were estimated from time to time using Dextrostix (Ames Co.). On day 3 a reading of 'less than $25 \mathrm{mg} / 100 \mathrm{ml}$ ' was found and a true blood glucose was $22 \mathrm{mg} / 100 \mathrm{ml}$. He was asymptomatic and no therapy other than a feed was given; 4 hours later he was pale, lethargic, cyanosed, and hypotonic. No colour registered on a Dextrostix test so after blood had been taken for true glucose estimation (later found to be $6 \mathrm{mg} / 100 \mathrm{ml}$ ) he was given intravenous glucose.

Investigations. An intravenous glucose tolerance test showed an inappropriately high fasting insulin level $(21 \mu \mathrm{U} / \mathrm{ml})$ when his blood glucose was $16 \mathrm{mg} / 100$ $\mathrm{ml}$. His urinary insulin excretion was very high, $66 \cdot 4$ $\mu \mathrm{U} / \mathrm{mg}$ creatinine (normal $1.25 \mu \mathrm{U} / \mathrm{mg}$ creatinine). As with his sister, other investigations were normal, including a leucine sensitivity test. Coeliac angiography performed before laparotomy showed no evidence of an insulinoma.

Treatment and progress. Initial attempts to control his hypoglycaemia included intravenous glucose, hydrocortisone, glucagon, and diazoxide, together with frequent milk feeds (with and without added sucrose). During this time he had both hypoglycaemic and nor- moglycaemic convulsions. The hypoglycaemia occurred more frequently on full-protein milk formula than on low-protein formula, suggesting at least a degree of protein-sensitivity (presumably not to branched chain amino acids since the leucine sensitivity test was normal). Full documentation of this protein-sensitivity did not seem justified since he was having recurrent hypoglycaemia, and at 15 weeks he had a laparotomy. No pancreatic tumour was palpable and the previous normal coeliac angiogram was confirmed by an injection of methylene blue. Subtotal pancreatectomy was therefore performed. The liver was grossly normal but to avoid hepatic damage due to possible leakage of pancreatic enzymes, no biopsy was taken.

His postoperative course was similar to his sister's. He was finally discharged at 19 weeks on a mediumprotein diet $(2 \cdot 2 \mathrm{~g} / \mathrm{kg}$ per day) with sucrose, as well as diazoxide ( $9 \mathrm{mg} / \mathrm{kg}$ per day), hydrochlorothiazide ( 1.5 $\mathrm{mg} / \mathrm{kg}$ per day), and phenobarbitone ( $9 \mathrm{mg} / \mathrm{kg}$ per day). By then his head circumference had fallen from the 90 th centile at birth to $<3$ rd centile; he had marked flexor head lag, hypertonia, and increased deep tendon reflexes, but good socialization.

$\mathrm{He}$ has required several hospitalizations for convulsions but general development has not been as slow as expected (for instance, he walked at 16 months). At age one year his protein restriction as well as his diazoxide were spontaneously discontinued by his mother, but no further hypoglycaemia has been observed.

Histology and histochemistry. Sections of pancreatic tissue from the first child were examined with fresh specimens from Case 2. Conventional histological stains (haematoxylin and eosin, aldehyde-fuchsin) showed the classical features described as nesidioblastosis (Yakovac et al., 1971). Silver impregnation and lead haematoxylin stains for endocrine granules showed diffuse hyperplasia of all types.

Immunohistochemical studies, carried out with antibodies to insulin, glucagon, and gastrin, showed that islet cells were highly reactive to both insulin and glucagon. Specifically stained cells were seen in well-formed islets or scattered throughout the pancreas. In many locations ductal formation was seen. Very few and scattered gastrin immunoreactive cells were also seen (Fig.). Ultrastructural studies, carried out on conventionally fixed tissue, showed the presence of four types of endocrine cells, $A, B, D$, and $D_{1}$ (Wiesbaden Classification-Solcia et al., 1973).

\section{Discussion}

To our knowledge this is the first report of nesidioblastosis in sibs. This raises interesting genetic and familial possibilities. Both sexes are represented so an autosomal recessive inheritance must be considered. The one normal child in the family, who was small-for-dates at birth $(2.5 \mathrm{~kg}$ at 39 weeks' gestation) had no neonatal hypoglycaemia. The father has subsequently had convulsions thought to be hysterical in origin; another 


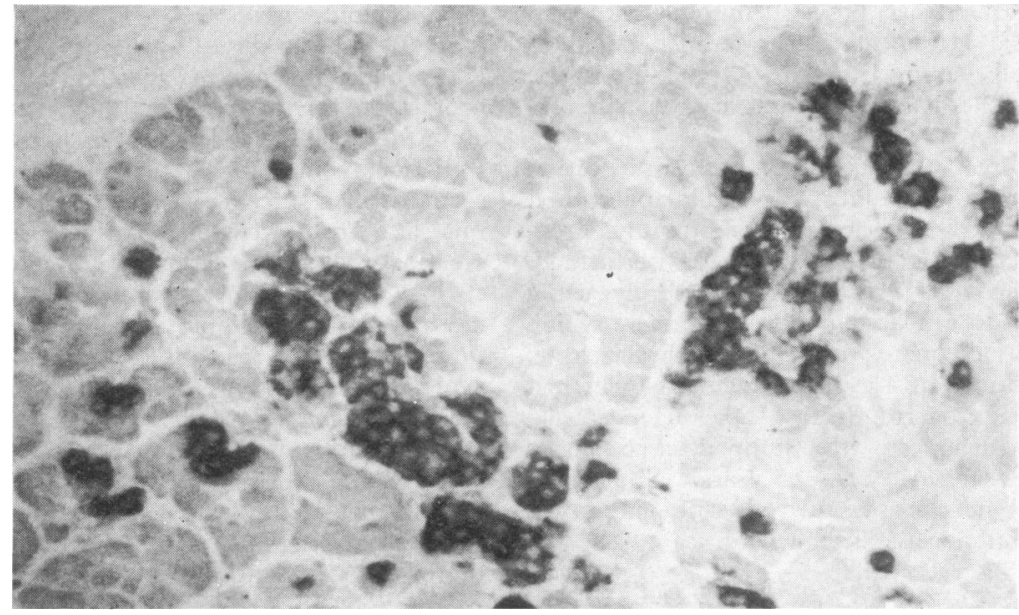

FIG.-Fragment of the pancreas, fixed in diethylpyrocarbonate paper (Pearse et al., 1974) and stained with an immunohistochemical method using antibodies to pure porcine insulin. Numerous B (insulin-producing) cells are stained as scattered elements or within the islets. $(\times 275$.

glucose tolerance test was normal. After counselling, the parents have decided not to have further children.

As in other reported cases (Yakovac et al., 1971; Grampa et al., 1974; Davidson et al., 1974; Sovik et al., 1975; Brown and Young, 1970), both children presented clinically with hypoglycaemia in the presence of hyperinsulinism, and both responded to treatment with diazoxide which suppresses insulin release (Baker et al., 1967). Also, as previously described (Sovik et al., 1975; Hamilton et al., 1967), subtotal pancreatectomy was required for complete control. We now feel that we should have proceeded to laparotomy immediately after initial investigations.

We believe this is the first report of this condition in which immunohistochemical methods have been used to show specific morphological evidence of the diffuse hyperplasia of the $\beta$ and sometimes $\alpha$ components of the pancreas. This visible evidence of insulin hyperplasia confirms one source of the raised serum insulin levels. Since these insulinproducing cells belong to the APUD series (Pearse, 1969), other cells might be involved as a result of their common origin from the neural crest; nonetheless, in agreement with clinical findings, the insulin compartment shows the greatest degree of participation.

As has been pointed out (Gellis, 1973), the histological diagnosis does not shed any light on actual aetiology, but delineates a subgroup in the condition of idiopathic hypoglycaemia. Concerning aetiology, it is possible that a hormone produced by the gut may be stimulating pancreatic insulin production. It would be interesting if samples of gut could be obtained at laparotomy for hormonal analysis, but at present the opportunity cannot be justified.

We feel, nonetheless, that the addition of immunohistochemical methods shows yet again the need for a multidisciplinary approach to a complicated clinical condition. In time perhaps, with more sophisticated methods, we can establish causes as well as effect control of idiopathic hypoglycaemia in the newborn.

We acknowledge the encouragement and advice of Professor Victor Dubowitz and Dr. Simon Godfrey, and the perseverance and patience of the neonatal nursing staff.

\section{REFERENCES}

Baker, L., Kaye, R., Root, A. W., and Prasad, A. L. N. (1967). Diazoxide treatment of idiopathic hypoglycemia of infancy. Fournal of Pediatrics, 71, 494.

Bloodworth, J. M. B., Jr., and Elliott, D. W. (1963). The histochemistry of pancreatic islet cell lesions. Fournal of the American Medical Association, 183, 1011.

Brown, R. E., and Madge, G. E. (1971). Cystic fibrosis and nesidioblastosis. Archives of Pathology, 92, 53.

Brown, R. E., and Still, W. J. S. (1968). Nesidioblastosis and the Zollinger-Ellison syndrome. American fournal of Digestive Diseases, 13, 656

Brown R. E., and Young, R. B. (1970). A possible role for the exocrine pancreas in the pathogenesis of neonatal leucinesensitive hypoglycemia. American fournal of Digestive Diseases, $15,65$.

Davidson, D. C., Blackwood, M. J., and Fox, E. G. (1974). Neonatal hypoglycaemia with congenital malformation of pancreatic islets. Archives of Disease in Childhood, 49, 151.

Gellis, S. (1973). Editor's comment. The Year Book of Pediatrics, p. 44. Year Book Medical Publishers, Chicago. 
Grampa, G., Gargantini, L., Grigolato, P. G., and Chiumello, G. (1974). Hypoglycemia in infancy caused by beta cell nesidioblastosis. American fournal of Diseases of Children, 128, 226.

Hamilton, J. P., Baker, L., Kaye, R., and Koop, C. E. (1967). Subtotal pancreatectomy in the management of severe persistent idiopathic hypoglycemia in children. Pediatrics, 39, 49.

Pearse, A. G. E. (1969). The cytochemistry and ultrastructure of polypeptide hormone-producing cells of the APUD series and the embryologic, physiologic, and pathologic implications of the concept. Fournal of Histochemistry and Cytochemistry, 17, 303.

Pearse, A. G. E., Polak, J. M., Adams, C., and Kendall, P. A. (1974). Diethylpyrocarbonate, a vapour-phase fixative for immunofluorescence studies on polypeptide hormones. Histochemical fournal, 6, 347.

Solcia, E., Pearse, A. G. E., Grube, D., Kobayashi, S., Bussolati, G. Creutzfeldt, W., and Gepts, W. (1973). Revised Wiesbaden classification of gut endocrine cells. Rendiconti di Gastroenterologia, 5, 13.

Sovik, O., Vidnes, J., and Falkmer, S. (1975). Persistent neonatal hypoglycaemia. Acta Pathologica et Microbiologica Scandinavica, 83A, 155.

Stern, C. (1973). Idiopathic hypoglycaemia. Proceedings of the Royal Society of Medicine, 66, 345.

Turner, D. S., and Marks, V. (1972). Enhancement of glucosestimulated insulin release by an intestinal polypeptide in rats. Lancet, 1, 1095.

Vance, J. E., Stoll, R. W., Kitabchi, A. E., Buchanan, K. D., Hollander, D., and Williams, R. H. (1972). Familial nesidioblastosis as the predominant manifestation of multiple endocrine adenomatosis. American fournal of Medicine, 52, 211.
Yakovac, W. C., Baker, L., and Hummeler, K. (1971). Beta cell nesidioblastosis in idiopathic hypoglycemia of infancy. Fournal of Pediatrics, 79, 226.

Correspondence to Dr. D. Woo, Department of Paediatrics, Hammersmith Hospital, Du Cane Road, London W12.

\section{Addendum}

The identification of nesidioblastosis in these children made us review the histology of a child who 16 years ago had a subtotal pancreatectomy for intractable hypoglycaemia. This girl, who is now a healthy symptom-free and intelligent young woman, was proved in retrospect to have nesidioblastosis of the pancreas.

Just before submission of this report, in July 1975, we were referred yet another case of prolonged refractory neonatal hypoglycaemia in a term Indian baby whose parents are from Mauritius. A subtotal pancreatectomy was performed at age 17 days and the immunohistochemical studies showed hyperplasia of only insulinsecreting cells, but to a greater degree than in any case we have seen before. She, too, has required continuing diazoxide therapy and we are hoping that a good neurological result will be attained. 